\title{
Obstetric outcome of teenage pregnancy in comparison with pregnant women of 20-29 years: a retrospective study
}

\author{
Atmaja Nair*, Sumangala Devi \\ Department of Obstetrics \& Gynaecology, Govt. Medical College, Kozhikode, Kerala, India
}

Received: 08 July 2015

Revised: 19 August 2015

Accepted: 31 August 2015

\section{*Correspondence:}

Dr. Atmaja Nair,

E-mail: atmajanair2001@gmail.com

Copyright: $\odot$ the author(s), publisher and licensee Medip Academy. This is an open-access article distributed under the terms of the Creative Commons Attribution Non-Commercial License, which permits unrestricted non-commercial use, distribution, and reproduction in any medium, provided the original work is properly cited.

\section{ABSTRACT}

Background: Adolescent pregnancy also called as teenage pregnancy is a major public health problem worldwide. Adolescence is defined by WHO as a period from 10-19 years. Adolescent pregnancy results from a number of factors like early marriage, lack of education, premarital sexual relations and lack of awareness regarding contraception. The impact of adolescent pregnancy on the teenager and her future generation is disastrous. This includes obstetric complications like anemia, hypertensive disorders, preterm labour, still births and low birth weight babies. The objective of the present study was to compare the obstetric outcome of teenage pregnancy with that of pregnant women of 20-29 years age group.

Methods: This was a hospital based retrospective case-control study conducted in a tertiary care teaching hospital in North Kerala from January 2013 to June 2013. Data collection was done from hospital records. The next delivery belonging to 20-29 years age group entered in parturition register after a teenage delivery was taken as control after satisfying inclusion and exclusion criteria. The obstetric outcome was recorded and analysed.

Results: The incidence of teenage pregnancy during the study period was $8.48 \% .90 .89 \%$ of teenage pregnant women were primigravidae. $40.7 \%$ were anaemic, $18.22 \%$ had preterm labor, $14.87 \%$ had preeclampsia and $29.5 \%$ of the babies had low birth weight.

Conclusions: Teenage pregnancy continues to be a major public health problem in India. The young age structure of Indian population favours more number of adolescents in the country. Preventing early marriages and delaying the onset of child bearing may go a long way in decreasing the number of teenage pregnancies.

Keywords: Adolescence, Teenage pregnancy, Adolescent pregnancy

\section{INTRODUCTION}

Adolescent pregnancy is a major public health problem worldwide. Adolescence is defined by WHO as a period from 10-19years. ${ }^{1}$ During this period, the structural, functional and psychosocial development occurs in a girl and prepares her for motherhood. According to WHO report-2005, one woman dies every minute due to pregnancy and childbirth related complications. ${ }^{2}$ This figure will definitely increase when a teenage girl becomes pregnant. The incidence of adolescent pregnancy in developing countries is about $19 \%$ with $3 \%$ pregnancies occurring before 15 years of age. The greatest incidence is in sub Saharan Africa followed by South Asia.

The factors leading to a teenage pregnancy are different in the Western world and in India. In the Western world, it is mainly because of lack of education, premarital sexual relations, and lack of awareness regarding 
contraception. But in India, teenage pregnancy is mostly because of early marriages and early child bearing.

Whatever be the cause, the impact of teenage pregnancy is on the teenage girl and her future generations. Teenage pregnancy affects the education of the girl child. Better education and a delay in family formation would give her better opportunities for skill development. Mothers with less education are less likely to educate their children. Teenage girls often get pregnant with older husbands. This large spousal age gap facilitates power-differentials between the girl and her partner. Teenage mothers are at increased risk of pregnancy complications like anaemia, hypertensive disorders and preterm labour. Inadequate antenatal care, lack of education and poor socioeconomic conditions also affect the outcome. ${ }^{3-5}$ Also there is increased risk of low birth weight babies, still births and perinatal deaths. ${ }^{6-8}$ Unmarried teen mothers are at increased risk of HIV and other sexually transmitted diseases.

According to UNFPA, the number of adolescent or teenage pregnancy depends on the extent of adolescent population in the world. The total population of adolescents will increase from 1.2 billion to 1.3 billion from 2010 to 2030, inspite of forecasted declines in fertility. By 2030, $15 \%$ of the female population worldwide will be represented by adolescents. ${ }^{9}$

Childmarriage and early confinement are well accepted custom in India. Poverty and ignorance magnifies this problem to a greater extent. ${ }^{10}$ According to National Family Health Survey-3, the incidence of teenage pregnancy in India was $16 \%$, with majority of them occurring in uneducated rural population. But in Kerala, the teenage pregnancy rate was $5.8 \% .^{11}$ Inadequate utilization of antenatal care facilities by these teenage mothers could be a major determinant in poor obstetric outcome. $^{12}$

The present study was conducted in a tertiary care teaching hospital in North Kerala to compare the obstetric outcome between teenage pregnancies and pregnancies in mothers of 20-29 years age group.

\section{METHODS}

This was a hospital based retrospective case-control study conducted in the Department of Obstetrics and Gynaecology in a tertiary care teaching hospital in North Kerala, from January 2013 to June 2013. The aim of the study was to assess the obstetric outcome of teenage pregnancy and to compare it with that of the control group.

The study group comprised of all teenage pregnant ladies admitted to the hospital during the study period. This included teenage patients admitted for medical termination of pregnancy, first and second trimester abortions and for delivery.
The control group comprised of gravida matched pregnant ladies of 20-29 years age group, delivered in the same hospital during the same period. An equal number of patients were selected as controls and to avoid selection bias, patients having the next entry in parturition register following a teenage pregnancy were selected. This group was chosen as control group because, adverse outcomes were expected to be least in this group. ${ }^{13}$ Candidates having major illnesses prior to pregnancy which could affect the outcome of pregnancy like heart disease, hypertension, diabetes mellitus and hypothyroidism were excluded from the study.

The complications and the outcome of the study group was analysed and the results were compared with that of the control group.

Data collection was done from the hospital-records. The history included marital and obstetric history. Investigation results and treatment history were analysed. The maternal complications, mode of delivery and details of the baby were documented.

The major complications analysed were anemia, pre eclampsia, preterm labour and low birth weight. Anemia was defined as a hemoglobin level below $10 \mathrm{gm} \%$ in the last trimester of pregnancy. Preeclampsia was defined as BP $>140 / 90$ on two occasions 4-6 weeks apart after 20 weeks of gestation, associated with proteinuria. Preterm labour was defined as delivery before 37 weeks of gestation. Low birth weight was defined as baby weight less than $2500 \mathrm{gm}^{13}$

Data analysis was done using SPSS software. Data was expressed as frequencies and percentages and was analysed by Chi square test for significance. Relative risk and $95 \%$ confidence interval for relative risk was calculated. A p value of $<0.05$ was considered to indicate statistical significance.

\section{RESULTS}

The total number of obstetric patients admitted to the hospital during the study period was 6660, of which 565 were teenagers, contributing to a teenage pregnancy rate of $8.48 \%$ (Table 1 ).

Table 1: Incidence of teenage pregnancy.

\begin{tabular}{|lll|}
\hline Admissions & Number & Percentage \\
\hline $\begin{array}{l}\text { Total No. of obstetrics } \\
\text { admissions }\end{array}$ & 6660 & 100 \\
\hline $\begin{array}{l}\text { Total No. of teenage } \\
\text { pregnancies }\end{array}$ & 565 & $8.48 \%$ \\
\hline
\end{tabular}

Only 2 of them were unmarried. All patients in control group were married (Table 2).

Out of 565 teenagers, 20 suffered $1^{\text {st }}$ trimester abortion, 4 had $2^{\text {nd }}$ trimester abortion, 1 underwent $1^{\text {st }}$ trimester MTP 
and 2 patients underwent $2^{\text {nd }}$ trimester MTP. The rest 538 teenagers were admitted for delivery. They were compared with 538 gravida-matched controls of 20-29 years age group (Table 3 ).

Table 2: Distribution according to marital status.

\begin{tabular}{|lll|}
\hline Marital status & Number & Percentage \\
\hline Married & 563 & $99.65 \%$ \\
\hline Unmarried & 2 & $0.365 \%$ \\
\hline Total & 565 & $100 \%$ \\
\hline
\end{tabular}

Table 3: Distribution according to termination of pregnancy.

\begin{tabular}{|lll|}
\hline Termination of pregnancy & Number & Percentage \\
\hline $1^{\text {st }}$ Trimester abortion & 20 & 3.54 \\
\hline $2^{\text {nd }}$ Trimester abortion & 4 & 0.71 \\
\hline $1^{\text {st }}$ Trimester MTP & 1 & 0.17 \\
\hline $2^{\text {nd }}$ Trimester MTP & 2 & 0.35 \\
\hline For delivery & 538 & 95.22 \\
\hline Total & 565 & $100 \%$ \\
\hline
\end{tabular}

So 538 teenage patients delivered during study period and were further analyzed and compared with control group.

489 patients in each group were primigravidae (90.89\%), 45 were the second gravidae and 4 were the third gravidae (Table 4).

Table 4: Distribution according to parity.

\begin{tabular}{|lll|}
\hline Parity & Number & Percentage \\
\hline Primigravida & 489 & $90.89 \%$ \\
\hline Secondgravida & 45 & $8.36 \%$ \\
\hline $3^{\text {rd }}$ gravida & 4 & $0.74 \%$ \\
\hline Total & 538 & $100 \%$ \\
\hline
\end{tabular}

Majority of teenage patients were 19 years old $(67.96 \%)$ (Table 5).

Table 5: Distribution of teenagers according to age.

\begin{tabular}{|lll|}
\hline Age & Number & Percentage \\
\hline 16 & 2 & 0.35 \\
\hline 17 & 6 & 1.06 \\
\hline 18 & 73 & 30.62 \\
\hline 19 & 384 & 67.96 \\
\hline Total & 565 & $100 \%$ \\
\hline
\end{tabular}

The majority of teenage patients were 19 years old $(67.96 \%)$.

The most common complications in both the groups were anaemia and preeclampsia. The relative risk for anaemia in teenager was $1.97(1.62-2.4)$ which was statistically significant with a $\mathrm{p}$ value $<0.0001$.
For preeclampsia, teenager had a relative risk of 2.76 (1.64-4.15), p value $<0.0001$ (Table 6). When comparing $\mathrm{Hb}$ levels less than $10 \mathrm{gm} \%$ with $\mathrm{Hb}>10 \mathrm{gm} \%$, teenager had a relative risk of $1.38(0.93-2.03)$ for having anaemia (p 0.133). None of the subjects in both group had severe anemia (Table 7).

Table 6: Distribution according to antenatal complications.

\begin{tabular}{|lllll|}
\hline Antenatal & \multicolumn{2}{c}{ Study group } & \multicolumn{2}{c|}{ Control group } \\
complications & No. & \% & No. & \% \\
\hline Anaemia & 219 & 40.7 & 111 & 20.63 \\
\hline Preeclampsia & 80 & 14.87 & 29 & 5.39 \\
\hline Eclampsia & 4 & 0.74 & 3 & 0.55 \\
\hline PROM & 35 & 6.50 & 36 & 6.69 \\
\hline IUGR & 32 & 5.94 & 21 & 3.90 \\
\hline Abruption & 4 & 0.74 & 5 & 0.93 \\
\hline Malpresentation & 15 & 2.78 & 16 & 2.97 \\
\hline Multiple pregnancy & 8 & 1.48 & 9 & 1.67 \\
\hline GDM & 6 & 1.11 & 12 & 2.23 \\
\hline
\end{tabular}

Table 7: Distribution according to haemoglobin level.

\begin{tabular}{|lllll|}
\hline \multirow{2}{*}{ Hblevel lel } & \multicolumn{2}{l}{ Study group } & \multicolumn{2}{c|}{ Control group } \\
\cline { 2 - 5 } & No. & $\%$ & No. & $\%$ \\
\hline$<7$ & 0 & 0 & 0 & 0 \\
\hline $7-9$ & 55 & 10.22 & 40 & 7.43 \\
\hline $9-10$ & 164 & 30.48 & 71 & 13.20 \\
\hline$>10$ & 319 & $59.29 \%$ & 427 & $79.37 \%$ \\
\hline Total & 538 & $100 \%$ & 538 & $100 \%$ \\
\hline
\end{tabular}

$18.22 \%$ in study group and $13.38 \%$ in control group had preterm labour; $\mathrm{p}$ value 0.037 . Teenager had a relative risk of 1.36 (1.03-1.8) for having a preterm delivery (Table 8).

Table 8: Distribution according to gestational age at delivery.

\begin{tabular}{|lllll|}
\hline \multirow{2}{*}{ Gestational age } & \multicolumn{2}{c}{ Study group } & \multicolumn{2}{c|}{ Control group } \\
\cline { 2 - 5 } & No. & \% & No. & \% \\
\hline <37 weeks & 98 & 18.22 & 72 & 13.38 \\
\hline $37-40$ weeks & 370 & 68.77 & 424 & 78.81 \\
\hline$>40$ weeks & 70 & 13.01 & 42 & 7.81 \\
\hline Total & 538 & $100 \%$ & 538 & $100 \%$ \\
\hline
\end{tabular}

$22.67 \%$ in study group and $24.53 \%$ in control group had caesarean section (Table 9).

118 pregnant teenagers and 120 control underwent primary CS. (Table 10).

Commonest indication for CS in both group were fetal distress, cephalopelvic disproportion and failed induction (Table 11). 
Table 9: Distribution according to obstetric outcome.

\begin{tabular}{|lllll|}
\hline \multirow{2}{*}{ Obstetric outcome } & \multicolumn{2}{c|}{ Study group } & \multicolumn{2}{c|}{ Control group } \\
\cline { 2 - 5 } & No. & \% & No. & \% \\
\hline Preterm labour & 98 & 18.22 & 72 & 13.38 \\
\hline CS & 122 & 22.67 & 132 & 24.53 \\
\hline VE & 13 & 2.41 & 229 & 4.08 \\
\hline Twin delivery & 8 & 1.48 & 9 & 1.67 \\
\hline IUD & 5 & 0.92 & 1 & 0.18 \\
\hline FTND & 292 & 54.27 & 302 & 56.13 \\
\hline Total & 538 & $100 \%$ & 538 & $100 \%$ \\
\hline
\end{tabular}

Table 10: Distribution of CS according to type.

\begin{tabular}{|lll|} 
Type of CS & $\begin{array}{l}\text { Study } \\
\text { group }\end{array}$ & $\begin{array}{l}\text { Control } \\
\text { group }\end{array}$ \\
\hline Primary CS & 118 & 120 \\
\hline Repeat CS & 4 & 12 \\
\hline Total & 122 & 132 \\
\hline
\end{tabular}

Table 11: Distribution according to major indications for CS.

\begin{tabular}{|lll|}
\hline Indication for CS & $\begin{array}{l}\text { Study } \\
\text { group }\end{array}$ & $\begin{array}{l}\text { Control } \\
\text { group }\end{array}$ \\
\hline Fetal distress & 36 & 30 \\
\hline CPD & 26 & 24 \\
\hline Failed induction & 24 & 21 \\
\hline
\end{tabular}

$29.49 \%$ in study group and $18.82 \%$ controls gave birth to low birth weight babies. The relative risk was 1.57 (1.261.95 ), $\mathrm{p}$ value of $<0.0001$ (Table 12).

Table 12: Distribution according to birth weight.

\begin{tabular}{|lllll|}
\hline \multirow{2}{*}{$\begin{array}{l}\text { Birth weight } \\
(\mathrm{kg})\end{array}$} & \multicolumn{2}{l}{ Study group } & \multicolumn{2}{c|}{ Control group } \\
\cline { 2 - 5 } & No. & \% & No. & \% \\
\hline 1.5 & 28 & 5.13 & 19 & 3.47 \\
\hline $1.5-1.99$ & 52 & 9.52 & 41 & 7.50 \\
\hline $2-2.49$ & 81 & 14.84 & 43 & 7.86 \\
\hline LBW babies & 161 & $29.49 \%$ & 103 & $18.83 \%$ \\
\hline$>2.5$ & 385 & $70.51 \%$ & 444 & 81.17 \\
\hline Total & 546 & $100 \%$ & 547 & 100 \\
\hline
\end{tabular}

\section{DISCUSSION}

Adolescent pregnancy continues to be a major public health problem in India. In our study, we got the incidence of teenage pregnancy as $8.48 \%$ which was comparable to the incidence noted by Rajoriya $\mathrm{M}$ et al. (2.5\%), Yasmin G et al. (5.1\%), Dubashi (4.5\%), Ambedkar (3.94\%) and Mamatha (10\%). But Prachi Saurabh Koranne et al. got an incidence of $24.17 \%$. $^{14-19}$

$99.65 \%$ of the teenagers in the present study were married, reflecting the tendency for early marriages in our part of the world. Studies by Yasmin G, Mulahopadhyay,
Mamatha and Dharmendra Raut showed similar results. $^{20,21}$

$90.89 \%$ of teenagers in our study were primi gravidae. Rajoriya M, Yasmin G, Prachi Saurabh Koranne and Mamatha got the same observation.

$78.9 \%$ of our teenagers were Muslims, as Muslims are a majority here and they practice early marriages. But Yasmin $\mathrm{G}$ and Dharmendra Raut observed more Hindu teenagers in their study $-64 \%$ and $60 \%$ respectively.

$40.7 \%$ of our teenagers were anemic. Other studies showed the incidence of anemia ranging from 22$75 \%$. $^{22,23}$

We found $14.87 \%$ preeclampsia in our teenagers, other studies showed an incidence of $7-32 \%{ }^{24}$

$18.22 \%$ of our teenagers delivered preterm, which was comparable to the findings of Rajoriya M (13\%), Mamatha (12.5\%) and Kavitha N. Singh (7.14\%). Anemia, preeclampsia and poor socioeconomic status would be the reason for preterm delivery. Prachi Saurabh Koranne got an incidence of 54.35\% - much higher than other studies.

In our study, $22.67 \%$ of teenagers underwent LSCS, the commonest indication being fetal distress followed by CPD. As the teenagers are still in the growing stage, inadequate growth of the pelvic bone could be the reason for CPD and fetal distress.

We found that $29.49 \%$ of babies born to teenagers were LBW, but other studies showed a much higher incidence of $39-65 \%$. Poor antenatal care, preeclampsia, IUGR, low socioeconomic status and spontaneous or induced preterm labour could be the cause of LBW babies.

\section{CONCLUSION}

Adolescent pregnancy and its associated complications are a matter of concern in developing countries. Adolescent pregnancy can result from unwanted fertility at an early age or due to young age structure of population. In India, the population growth is mainly due to the current age structure. The existing young age structure will be responsible for $33.6 \%$ of population growth from 2010-2050. This young age structure is not amenable to modification. Also child marriage and adolescent pregnancy are well accepted in India. Law permits the marriage of a girl only after the age of 18 . By encouraging delayed marriages, delayed child bearing and wider spacing between births, communities and families can contribute to a healthier population. Girls should be well educated and empowered to take decisions, so that they can transform their own lives and live with dignity. 
Funding: No funding sources

Conflict of interest: None declared

Ethical approval: The study was approved by the institutional ethics committee

\section{REFERENCES}

1. WHO. Programming for adolescent health and development. WHO Technical Report Series 886. Geneva: WHO; 1999: 1-217.

2. WHO. The World Health Report, 2005. Make every mother and child count, 2005. Available at: http://www.who.int/whr/2005/en/.

3. Bhaduria S. Teenage pregnancy: a retrospective study. J Obstet Gynaecol India. 1991;41:454-6.

4. Kale KM. Socio-medical correlates of teenage pregnancy. J Obstet Gynaecol India. 1996;46:180-4.

5. Pal A, Gupta KB, Randhawa I. Adolescent pregnancy: a high risk group. J Indian Med Assoc. 1997;95:127-8.

6. Verma V, Dask KB. Teenage Primi gravidae: a comparative study. Indian $\mathrm{J}$ Public Health. 1997;412:52-5.

7. Chhabra S. Perinatal outcome in teenage mothers. J Obstet Gynaecol India. 1991;41:30-2.

8. Bhalerao AR, Desai SV, Dastur NA, Daftary SN. Outcome of teenage pregnancy. J Postgrad Med. 1990;36:136-9.

9. Edilberto Loaiza, Mengjia Liang. Adolescent pregnancy. In: Edilberto Loaiza, Mengjia Liang, eds. A Review of the Evidence UNFPA. New York: UNFPA; 2013: 8-10.

10. Nitwe MT. Teenage pregnancy. A health hazard. J Obstet Gynaecol India. 1989;39:303-6.

11. National Family Health Survey India. Key findings from NFHS-3. International Institute of Population Sciences, Mumbai, India, 2015. Available at: http://www. Nfhsindia.org/factsheet.html. Accessed 10 March 2015.

12. Loto OM, Ezechi OC, Kalu BKE. Poor obstetric performance of teenagers. Is it age or quality of carerelated? J Obstet Gynaecol. 2004;24:395-8.
13. Park K. Parks text book of preventive and social medicine. In: Park K, eds. 21st ed. Jabalpur, India: M/s. Banarsidas Bhanot Publishers; 2011.

14. Rajoriya M, Kalra R. Challenges of motherhood in adolescent girls. Int J Reprod Contracept Obstet Gynaecol. 2015;4:696-700.

15. Ghazala Yasmin, Aruna Kumar, Bharti Parihar. A study of sociodemographic factors of teenage pregnancy at a tertiary care centre. J Evol Med Dent Sci. 2014;3(4):1020-5.

16. Dubashi S, Wani R. Teenage pregnancy. Bombay Hosp J. 2008;50(2):236-9.

17. Ambedkar NN, Khandait DW, Zodpey SP, Kasturwar NB, Vasudeo ND. Teenage pregnancy outcome. A record based study. Indian J Med Sci. 1999;53:14-7.

18. Mamatha S. Adolescent pregnancy: trends and determinants. J Evol Med Dent Sci. 2014;3(57):12910-26.

19. Prachi Saurabh Koranne, Aparna R. Wahane. Pregnancy in adolescence: is it really a concern? J Evol Med Dent Sci. 2014;4(28):7659-68.

20. Mukhopadhyay $P$, Chaudhuri RN, Bhaskar P. Hospital based perinatal outcomes and complications in teenage pregnancy in India. J Health Popul Nutr. 2010;28(5):494-500.

21. Dharmendra Raut, Amol Patil. Study of comparison of pregnancy and fetal outcome among the pregnant adolescent (13-19 years) and control (20-25 years) groups. J Evol Med Dent Sci. 2014;3(73):15374-80.

22. Kumar A, Singh T, Basu S, Pandey S. Outcome of teenage pregnancy. Indian $\mathrm{J}$ Pediatr. 2007;74(10):927-31.

23. Padmasri Devi P, Kiran Deedi M. Ch. Ganapathy Swamy V. Sarojini. Risk of low birth weight infants in teenage pregnancy. J Evol Med Dent Sci. 2014;3(52):12164-70.

24. Singh KN. Outcome in adolescent pregnancy. J Obstet Gynaecol India. 2001;51(6):34-6.

Cite this article as: Nair A, Devi S. Obstetric outcome of teenage pregnancy in comparison with pregnant women of 20-29 years: a retrospective study. Int J Reprod Contracept Obstet Gynecol 2015;4:1319-23. 